Volume. 4 Nomor. 1

Periode: Juli - Desember 2020; hal. 10-21

p-ISSN : 2580-1112; e-ISSN : 2655-6669

Copyrighr @2020

Penulis memiliki hak cipta atas artikel ini

journal homepage: https://ejournal.akperfatmawati.ac.id

DOI : $10.46749 /$ jiko.v3i2.35
Jurnal Ilmiah Keperawatan Orthopedi

(JIKO)

Article history:

Received: Desember 12, 19

Revised: September 05, 20

Accepted: September 09, 20

\title{
Pengetahuan dan Sikap Anak Tentang Mobilisasi Dini
}

\author{
Sudarmi ${ }^{1}$, Ayuda Nia Agustina ${ }^{2}$ \\ Akademi Keperawatan Fatmawati, Jakarta
}

\begin{abstract}
Abstrak
Mobilisasi dini merupakan salah satu program yang dibuat untuk mendukung penyembuhan kondisi pasien. Pelaksanaan mobilisasi dini dapat dilakukan segera setelah pasien sadar atau setelah dianjurkan oleh dokter atau perawat. Akan tetapi, kebanyakan pasien paska operasi appendectomy lebih sering berbaring di tempat tidur. Hal tersebut dikarenakan pasien merasa takut jahitan pada luka operasi akan robek dan tidak sembuh. Apabila tidak segera ditangani, akan mengakibatkan berbagai macam dampak negatif. Penelitian ini menganalisis pengetahuan dan perilaku pasien anak paska operasi appendectomy tentang mobilisasi dini di RSUP Fatmawati Jakarta. Jenis penelitian ini adalah kualitatif, pengumpulan data menggunakan metode wawancara mendalam dan observasi perilaku pasien selama mobilisasi dini. Hasil penelitian menunjukkan bahwa ketakutan akan lepasnya atau robeknya jahitan pada luka operasi menjadi penyebab pasien malas melakukan mobilisasi dini dan ketidaktahuan pasien akan manfaat dan tujuan mobilisasi dini. Diharapkan perawat dapat memberikan informasi kepada pasien dan keluarga tentang mobilisasi dini menggunakan media seperti lembar balik ataupun video sebelum pasien itu menjalani operasi agar penerapan mobilisasi dini dapat optimal.
\end{abstract}

Kata Kunci: Appendectomy, Mobilisasi Dini, Paska Operasi, Penyembuhan Luka.

\section{Abstract}

Early mobilization is one of the programs created to support the healing of the patient's condition. Early mobilization can be done as soon as the patient is awake or after being recommended by a doctor or nurse. However, most patient are more often lying in bed. That is because the patient was afraid that the stitches on the surgical wound would tear and not heal. If not treated immediately, it will result in various negative impacts. This study analyzed the knowledge and behavior of pediatric patients after appendectomy about early mobilization in Fatmawati General Hospital, Jakarta. This type of research is qualitative, data collection using in-depth interview and observation of patient behavior during early mobilization. The results showed that fear of the removal or tearing of the sutures in the surgical wound caused the patient to be lazy in early mobilization and the patient's ignorance of the benefits and purpose of early mobilization. It is expected that nurses can provide information to patients and families about early mobilization using media such as flip sheets or videos before the patient underwent surgery so that the application of early mobilization can be optimized.

\footnotetext{
${ }^{1}$ e-mail: n.sudarmiharun@gmail.com

2 e-mail: ayudania@akperfatmawati.ac.id
} 
Keywords: Appendectomy, Early Mobilization, Post-Surgery, Wound Healing.

Dendahuluan

Appendectomy atau operasi pengangkatan usus buntu merupakan kedaruratan bedah abdomen yang sering dilakukan di berbagai negara di seluruh dunia. Di Amerika Serikat, lebih dari 250.000 appendectomy dilaksanakan setiap tahun (Cetrione, 2009). Insiden appendiksitis cenderung stabil di Amerika Serikat selama 30 tahun terakhir, sedangkan insiden appendiksitis lebih rendah di negara berkembang dan negara terbelakang, terutama negara-negara Afrika, dan lebih jarang pada kelompok sosio ekonomi rendah. Di Indonesia insiden appendiksitis cukup tinggi, terlihat dengan adanya peningkatan jumlah pasien dari tahun ke tahun. Berdasarkan data yang diperoleh dari Kementrian Kesehatan Republik Indonesia (2015) nampak bahwa kasus appendikitis pada tahun 2015 sebanyak 65.755 orang dan pada tahun 2016 jumlah pasien appendicitis sebanyak 75.601 orang.

Insiden apendisitis di negara maju lebih tinggi dari pada negara berkembang. Amerika menangani 11 kasus/10.000 kasus apendisitis setiap tahun. Menurut data RSPAD Gatot Subroto tahun 2008 jumlah pasien yang menderita apendisitis di Indonesia adalah sekitar $32 \%$ dari jumlah populasi penduduk Indonesia (DEPKES RI, 2010). Insiden apendisitis juga menduduki peringkat yang cukup signifikan di RSUD Arifin Achmad Pekanbaru tahun 2009, apendisitis menempati urutan ke-4 dengan jumlah pasien sebanyak 186 orang. Meskipun pada tahun berikutnya apendisitis menempati urutan ke-5, jumlah pasien apendiktomi meningkat yakni sebanyak 203 orang. Tahun 2011 pasien apendiktomi mengalami peningkatan yang lebih signifikan dengan menempati urutan ke-3 di RSUD Arifin Achmad dengan kasus terbanyak yakni 283 orang (Medikal Record RSUD Arifin Achmad Pekanbaru, 2011). Berdasarkan hasil berdinas di Instalasi GPS jumlah pasien pasca operasi appendectomy tidak kurang dari 20 pasien setiap bulannya, sedangkan berdasarkan data yang didapat selama periode 2 tahun (Januari 2016-April 2018) terdapat 475 pasien yang menjalani appendectomy dengan lama hari rawat rata-rata 3 hari. Salah satu program perawatan yang penting untuk mendukung kesembuhan pasien adalah dengan membantu pasien melakukan mobilisasi dini setelah operasi.

Anak yang mengalami prosedur pembedahan, seperti appendictomy akan menyebabkan berbagai macam stres. Kondisi paska operasi dengan adanya luka di bagian tubuh pasien, menyebabkan pasien merasa nyeri sehingga pergerakan pun akan terbatas. Pasien dengan pasca operasi appendectomy biasanya lebih sering berbaring di tempat tidur karena pasien masih mempunyai rasa takut untuk bergerak. Di samping itu, kurangnya pemahaman pasien dan keluarga mengenai mobilisasi juga menyebabkan pasien enggan untuk melakukan pergerakan pasca operasi. Pada pasien pasca operasi seperti operasi usus buntu (appendectomy), sangat penting untuk melakukan pergerakan atau mobilisasi. Banyak masalah yang akan timbul apabila pasien paska operasi tidak melakukan mobilisasi sesegera mungkin, seperti pasien tidak dapat buang air kecil (retensi urin), perut menjadi kaku (distensi abdomen), terjadi kekakuan otot, dan sirkulasi darah tidak lancar (Smeltzer, 2010). Keadaan tersebut, apabila terus dibiarkan akan menyebabkan penyembuhan luka yang lama dan lama hari rawat di rumah sakit jadi memanjang.

Mobilisasi dini merupakan intervensi keperawatan yang diberikan oleh perawat kepada pasien sebelum pasien mendapatkan prosedur operasi appendictomy melalui edukasi kesehatan 
menggunakan media lembar balik atau menonton video. Edukasi kesehatan tentang mobilisasi dini dapat diberikan dengan didampingi keluarga pasien. Karena, nantinya keluarga yang melatih mobilisasi dini.

Mobilisasi dini dimaksudkan sebagai upaya untuk mempercepat penyembuhan dari suatu cedera atau penyakit tertentu yang telah merubah cara hidup yang normal. Pada 6 jam pertama pasien harus tirah baring dahulu, namun pasien dapat melakukan mobilisasi dini dengan menggerakkan lengan atau tangan, memutar pergelangan kaki, mengangkat tumit, menegangkan otot betis, serta menekuk dan menggeser kaki. Setelah 6-10 jam, pasien diharuskan untuk dapat miring ke kiri dan ke kanan untuk mencegah trombosis dan tromboemboli. Setelah 24 jam pasien dianjurkan untuk dapat belajar duduk. Setelah pasien dapat duduk, dianjurkan untuk belajar berjalan.

Beberapa tujuan dari mobilisasi antara lain: mempertahankan fungsi tubuh, memperlancar peredaran darah, membantu pernafasan menjadi lebih baik, mempertahankan tonus otot, memperlancar eliminasi alvi dan urine, mengembalikan aktivitas tertentu sehingga pasien dapat kembali normal atau dapat memenuhi kebutuhan gerak harian (Ditya, 2016).

Banyak penelitian yang menyatakan bahwa mobilisasi dini sangat bermanfaat dan membantu proses penyembuhan luka paska operasi appendictomy. Hasil penelitian yang dilakukan oleh Riswanto pada tahun 2015, didapatkan data bahwa dari 11 orang pasien pasca operasi yang melakukan ambulasi dini ditemukan ada 2 orang pasien $(18,2 \%)$ yang mengalami retensi urin dan 9 orang $(81,8 \%)$ lainnya dapat berkemih secara spontan, sedangkan pada 5 orang pasien yang tidak melakukan ambulasi dini pasca operasi, 4 orang $(80 \%)$ diantaranya mengalami retensi urin dan 1 orang $(20 \%)$ dapat berkemih secara spontan. Berdasarkan hasil wawancara dengan salah seorang perawat yang bertugas di Irna RSUP Fatmawati, tidak jarang ditemukan pasien pasca operasi appendectomy mengalami infeksi sehingga biasanya rata-rata hari rawat hanya 3 hari menjadi 5-7 hari.

Berdasarkan hasil studi pendahuluan di Instalasi Gedung Profesor Soelarto (GPS) RSUP Fatmawati dengan melakukan observasi dan wawancara pada dua orang pasien paska operasi appendectomy diperoleh data bahwa pasien hanya terlentang di tempat tidur, terkadang mengubah posisi miring kanan dan kiri dengan wajah tampak meringis dan takut untuk melakukan pergerakan. Salah seorang keluarga pasien mengetahui bahwa pergerakan pasca operasi sangat penting untuk mempercepat proses penyembuhan sehingga tidak memperpanjang lamanya hari rawat, akan tetapi karena pasien merasa kondisinya lemah dan khawatir jahitan pada luka operasinya terlepas, pasienenggan untuk melakukan mobilisasi meskipun keluarga pasien telah membantu untuk mobilisasi, tetapi pada akhirnya pasien menyadari dan mau untuk melakukan mobilisasi pada hari keempat pasca operasi dengan berjalanjalan ke luar kamar.

Salah seorang pasien yang lain mengatakan bahwa ia tidak berani untuk melakukan pergerakan karena takut luka jahitannya terlepas. Selain itu kurangnya informasi dari petugas kesehatan mengenai mobilisasi dini juga membuat pasien tersebut tidak melakukan mobilisasi. Berdasarkan observasi di lapangan dan uraian di atas menunjukkan bahwa pasien pasca operasi appendectomy kurang mengetahui tentang mobilisasi dini pasca operasi sehingga pasien masih enggan dan khawatir untuk melakukan pergerakan. Maka peneliti tertarik untuk menganalisis pengetahuan dan sikap pasien paska operasi appendictomy tentang mobilisasi dini. 


\section{Metode}

Penelitian ini merupakan penelitian kualitatif dengan pendekatan fenomenologi. Partisipan adalah seluruh pasien paska operasi appendiktomy lebih dari 6-8 jam, telah menikah, berusia 1950 tahun dan pernah dirawat di RSUP Fatmawati. Partisipan dipilih dengan menggunakan tehnik purposive sampling (sesuai tujuan) dengan fokus penelitian kualitatif dengan kedalaman dan proses serta pencapaian saturasi dan variasi data. Penelitian ini melibatkan 4 orang partisipan.

Penelitian dilakukan di RSUP Fatmawati dengan memperhatikan prinsip-prinsip etik, yaitu memberikan manfaat untuk partisipan dan keluarga, memberikan kebebasan pada partisipan untuk memilih berpartisipasi atau tidak dalam penelitian, menjaga privasi partisipan, mempertahankan kenyamanan dan bersikap adil. Pengumpulan data dilakukan dengan metode wawancara mendalam ditambah dengan catatan lapangan.

Peneliti mengajukan permohonan surat izin untuk melaksanakan penelitian di RSUP Fatmawati, selanjutnya peneliti melakukan orientasi terhadap partisipan dengan membina hubungan saling percaya, melakukan pendekatan yang disesuaikan dengan latar belakang sosial budaya agar partisipan merasa nyaman dan dapat memberikan informasi yang dibutuhkan. Tahapan selanjutnya peneliti mengumpulkan data menggunakan wawancara mendalam.

Sebelum dilakukan wawancara, calon partisipan diberikan penjelasan tentang maksud dan tujuan penelitian dengan memberikan informed consent. Wawancara dilakukan selama 30-45 menit dilengkapi dengan digital voice recorder dan catatan lapangan. Pada tahap terminasi dilakukan konfirmasi hasil wawancara pada semua partisipan.
Manajemen data dilakukan pada hasil wawancara dan catatan lapangan. Hasil dokumentasi dibuat dalam bentuk transkrip verbatim yang disimpan dalam file word dan dijadikan folder selanjutnya disimpan dalam hard disk laptop dan diberikan password.

Analisis data dilakukan menggunakan model Collaizi (1978) yaitu dengan melakukan klarifikasi hasil analisa data dengan mendatangi kembali saat diperlukan konfirmasi data. Adapun keabsahan data dalam penelitian ini menggunakan prinsip credibility (kredibilitas), dependability (kestabilan data), confirmability (objektivitas), dan transferability (validitas) (Afiyanti \& Rachmawati, 2014)

\section{Hasil Penelitian}

Penelitian ini melibatkan 4 (empat) orang partisipan inti, yaitu pasien. Pasien terdiri dari 2 (dua) orang perempuan dan 2 (dua) orang laki-laki. Usia rata-rata 33.75 tahun dengan rentang usia termuda 20 tahun dan tertua 49 tahun. Semua partisipan beragama islam dengan pendidikan 3 orang tamat SD, 1 orang tamat SMA, status pekerjaan bervariasi yang antara lain 1 orang sebagai ibu rumah tangga, dan 1 orang sopir, 1 orang karyawan swasta, dan 1 orang pedagang.

Selain itu, penelitian ini melibatkan 2 (dua) orang partisipan pendukung $(\mathrm{Pp})$ dari petugas kesehatan dan 4 (empat) orang partisipan pendukung dari keluarga (Pk). Dua orang partisipan pendukung yang berasal dari petugas kesehatan yaitu dokter spesialis bedah dan ners. Sementara 4 (empat) orang partisipan dengan pendidikan akhir SMA/SMK dan status pekerjaan bervariasi, 1 orang pelajar, 2 orang karyawan swasta dan 1 orang satpam.

Penelitian ini mendapatkan 9 tema, yaitu: 1) Pengertian mobiliasi dini, 2) Tujuan mobilisasi dini, 3) Tahapantahapan mobilisasi dini, 4) Manfaat mobilisasi dini, 5) Perilaku mobilisasi dini di hari pertama sampai dengan 
ketiga, 6) Ketakutan dan nyeri untuk melakukan mobilisasi dini segera, 7) Instruksi dokter atau perawat untuk melakukan mobilisasi dini, 8) Dukungan keluarga untuk melakukan mobilisasi dini, 9) Harapan setelah melakukan mobilisasi dini.

\section{Pengetahuan tentang pengertian mobilisasi dini}

semua partisipan inti mengatakan bahwa mereka tidak mengetahui dan tidak mengerti mengenai pengertian mobilisasi dini karena belum pernah mendapatkan pengalaman operasi pada diri sendiri ataupun keluarga. Seperti pernyataan yang disampaikan oleh (P1) dan (P3) berikut ini :

"Saya nggak tahu tuh mbak apa yang dimaksud dengan pergerakan setelah operasi soalnya belum dikasih tahu jadi saya nggak tahu."...... (Pl)

"Sebelumnya saya nggak tahu dan nggak pernah denger tentang ngelakuin pergerakan setelah operasi orang kejadiannya mendadak gini, sebelumnya juga nggak ngerasain apa-apa orang waktu itu selesai dagang terus makan eh langsung perutnya mules jadi harus dilakukan tindakan operasi karena takutnya pecah di dalam nanti malah biayanya lebih mahal."....... (P3)

Begitu pula dengan keluarga masing-masing pasien saat ditanyakan mengenai pengertian mobilisasi dini. Hampir semua partisipan pendukung keluarga (Pk) juga mengatakan bahwa kurang mengetahui tentang pengertian mobilisasi dini. Seperti pernyataan yang disampaikan oleh $(\mathrm{Pk} 3)$ berikut ini:

"Kalo disuruh ngejelasin saya bingung mbak, nggak tahu mau jelasin apa soalnya saya kurang tahu apa itu pergerakan setelah operasi...paling kalo ngelakuin pergerakan setelah operasi bisa bikin badan nggak pada kaku,,,itu kali ya mbak."..... (Pk3)

\section{Pengetahuan tentang tujuan mobilisasi dini}

Beberapa partisipan menyebutkan tujuan dari melakukan pergerakan adalah untuk mempercepat proses penyembuhan, memperpendek masa sakit atau perawatan, agar keadaan tubuh dapat kembali pada kondisi sebelum sakit sehingga dapat beraktivitas seperti biasa. Seperti ungkapan P2 berikut ini :

"ya tujuannya biar saya cepat sembuh, biar kondisi saya pulih kaya sebelum sakit, biar bisa kerja lagi"............(P2)

$\begin{array}{ccc}\text { "kalau menurut } & \text { saya, kita } \\ \text { melakukan sesuatu } & \text { pasti } \quad \text { ada }\end{array}$
tujuannya, dan pasti tujuannya baik untuk kita...kaya saya melakukan pergerakan biar badan saya enakan, terus biar cepat pulang, dan bisa kerja lagi"..................(P4)

Pengetahuan tentang Tahap-Tahap Mobilisasi Dini

Terdapat partisipan mengatakan bahwa mobilisasi dini dilakukan jika sudah ada instruksi dari perawat atau dokter. Ada pula partisipan yang menjawab tidak mengetahui, bingung harus mengikuti informasi yang mana untuk memulai melakukan mobilisasi dini. Seperti yang diungkapkan (P1) dan (P2) berikut ini:

"saya kan tadi malam operasi sekitar jam 10, trus paginya pas dokter datang katanya jangan banyak gerak dulu jadi saya belum melakukan pergerakan paling cuma gerak-gerakin kaki aja, trus tadi pas jam 12 sama perawat katanya silahkan boleh makan trus digerakin, miring kanan miring kiri biar bisa buang gas' gitu katanya...saya nggak tahu kapan sebenernya harus gerak-gerakin badan, saya mah tunggu dibolehin sama dokternya aja baru saya berani gerak-gerak"........ (P1)

"tadi sih ada yang bilang coba miring ke kiri dan miring ke kanan trus duduk...tapi ada juga yang bilang jangan digerakin dulu katanya tunggu 24 jam dulu baru boleh duduk, jadi bingung mau ikutin saran yang mana.".......(P3)

Menurut pendapat perawat, pasien pasca operasi appendectomy diperbolehkan melakukan pergerakan 24 
jam setelah operasi karena dikhawatirkan jika terlalu dini melakukan mobilisasi dapat terjadi kelumpuhan, mual, pusing. Hal tersebut terjadi karena pengaruh anestesi spinal dimana rata-rata pasien yang menjalani operasi appendectomy menggunakan anestesi tersebut. Seperti ungkapan berikut ini:

"Biasanya kalau di sini pasien yang telah menjalani operasi diperbolehkan untuk melakukan mobilisasi dini yaitu 24 jam setelah operasi itu untuk pasien yang dengan anestesi spinal baru boleh melakukan pergerakan, walaupun dalam teori disebutkan 6-8 jam pertama setelah operasi sudah boleh melakukan pergerakan...karena ditakutkan ya efek dari anestesinya itu, apalagi kalau pasien dengan anestesi spinal ditakutkan kalau terlalu dini mobilisasinya nanti terjadi kelumpuhan atau mungkin pasien itu merasa pusing, mual...tetapi kalau pasien yang dianestesi umum itu biasanya sih 12 jam setelah operasi sudah boleh melakukan pergerakan"..... (Pp2)

Untuk tahapan gerakan yang dilatih pada mobilisasi dini, jawaban partisipan bervariasi. Gerakan yang dilakkan pada hari pertama paska operasi adalah miring kanan-miring kiri yang diberitahukan oleh dokter, pada hari kedua duduk dan berjalan, pada hari ketiga sama degan gerakan yang dilakukan pada hari sebelumnya. Hal tersebut seperti yang diungkapkan oleh (P1) dan (P2) sebagai berikut ini:

"saya nggak tahu...cuma tadi sih dokternya bilang katanya miring-miring ke kiri trus ke kanan, abis itu boleh duduk trus jalan...”(Pl)

"paling besok (hari kedua setelah operasi) sudah boleh jalan...sebenernya sekarang juga sudah boleh jalan tapi saya nggak berani, nggak kuat soalnya kepalanya sakit" (P2)

\section{Pengetahuan tentang manfaat mobilisasi dini}

Berdasarkan hasil wawancara mendalam dengan partisipan, didapatkan hasil bahwa ada seorang partisipan yang mengatakan tidak mengetahui manfaat melakukan pergerakan setelah operasi.

Hal tersebut diakui partisipan karena dirinya belum diberi tahu oleh perawat yang bertugas. Sedangkan tiga partisipan lainnya mengatakan bahwa manfaat dari melakukan mobilisasi setelah operasi adalah agar aliran darah dalam tubuh jadi lancar sehingga badan tidak terasa pegal, untuk pemulihan kondisi tubuh misalnya angin yang ada dalam perut dapat keluar dan bisa memperlancar buang air kecil, kemudian agar kaki tidak terasa kaku sehingga dapat cepat pulang dan tidak terlalu lama dirawat di rumah sakit. Seperti yang diungkapkan (P1) dan (P4) sebagai berikut:

"saya nggak tahu...kan belum dikasih tahu sama dokter sama perawatnya juga belum dikasih tahu kalau gerak-gerakin badan itu untuk apa,,,jadi ya saya nggak tahu untuk apa..."...... .(P1)

"ya... kalau saya pikir mah buat pemulihan kondisi saya berarti kalau sudah bisa bergerak mungkin saya sudah pulih, saya mah saya ikutin aja kan katanya begini-begini, saya juga kalau diam aja kan nggak betah jadi saya lebih enak bergerak...kadang-kadang saya miringin jadi bisa keluar kentutnya gitu kan kaya pipis juga ya biar bisa keluar jadi ya cari enaknya aja gitu...menurut saya ya ada pengaruhnya juga..." (P4)

Sebagian besar partisipan dari pihak keluarga juga mengatakan bahwa manfaat dari melakukan pergerakan setelah operasi adalah agardarahnya tidak beku, melancarkan aliran darah, dan agar badan tidakkaku. Seperti ungkapan (Pk3) berikut ini:

"ya...itu seperti yang saya baca di mading depan manfaatnya untuk ya biar darah nggak beku, melancarkan peredaran darah, untuk apa lagi ya mba saya lupa tapi yang saya ingat dari baca di mading ya untuk itu...ya tahunya juga waktu itu dari teman juga pas lagi jenguk 
ibu katanya kalau nanti sudah enakan miring kiri miring kanan, saya tanya tahunya dari mana katanya itu ada di mading depan.".... (P3)

Berdasarkan hasil wawancara diketahui bahwa masih ada partisipan yang tidak tahu mengenai mobilisasi dini.Hal tersebut dikarenakan partisipan belum pernah mendapatkan informasi sebelumnya mengenai mobilisasi dini sebelum operasi dilaksanakan atau memang partisipan belum pernah mendengar mengenai pergerakanc setelah operasi.

Hal itu disebabkan beberapa pasien menjalani operasi secara mendadak atau tiba-tiba (cyto) tanpa ada perencanaan atauharus menginap terlebih dahulu di ruang rawat inap. Informan jugamengaku tidak mendapat informasi dari perawat sebelum operasihanya setelah operasi perawat menganjurkan untuk mulai melakukanpergerakan. Seperti ungkapan P1 berikut ini:

"saya sebelumnya nggak pernah dapat informasi tentang pergerakan setelah operasi, paling baru dapat informasinya pas sudah operasi pagipaginya dikasih tahu dokter buat gerakgerak terus sama perawatnya juga disuruh gerak-gerak, itu aja...”........ (P1)

Perilaku mobilisasi dini pada hari pertama sampai dengan hari ketiga setelah operasi

Semua partispan mengatakan bahwa mereka baru berani untuk melakukan mobilisasi dini kurang lebih 10-12 jam setelah operasi dan jika sudah diperbolehkan oleh dokter atau perawat untuk melakukan pergerakan. pada hari pertama adalah miring kanan miring kiri, mengangkat tangan, dan mengangkat kaki. Pernyataan tersebut dapat dilihat oleh (P1) dan (P2) berikut ini:

"tadi sekitar jam 9an atau 1/2 10an saya sudah bisa gerak-gerakin kaki sama miring ke kiri miring ke kanan, soalnya tadi perawatnya bilang suruh miringmiring... jadi ya kalau dihitung-hitung sekitar 10 jam abis operasi saya baru bisa gerak-gerakin kaki." (P1)

"tadi sih sekitar jam 8an saya mulai gerak-gerakin kaki padahal saya operasi jam 1/2 9 malam tapi saya baru bisa gerak-gerakin tadi pagi jam 8, saya disuruh juga miring kiri dan miring kanan terus saya ikutin juga jadi saya sudah berani miring kiri miring kanan".... .(P2)

Perilaku mobilisasi dini pada keempat partisipan di hari kedua setelah operasi beraneka ragam. Tiga partisipan sudah mulai berani untuk duduk dan berjalan, selain itu terdapat seorang partisipan yang belum berani untuk jalan karena takut untuk turun dari tempat tidur yang agak tinggi menurutnya. Pernyataan tersebut dapat dilihat dari pernyataan (P1) dan (P2) sebagai berikut:

"hari ini saya sudah bisa duduk, tadi juga sudah duduk pas makan, hanya saja saya belum berani ke kamar mandi karena saya belum berani turun soalnya tempat tidurnya tinggi....”..... (P1)

“...tadi sudah jalan-jalan ini juga sudah duduk soalnya dokternya bilang jangan tiduran mulu jalan aja sambil jalan-jalan sedikit...”.....(P2)

Perilaku mobilisasi dini pada keempat partisipan di hari ketiga yaitu duduk, berjalan di ruangan atau ke kamar mandi. Hal ini seperti pernyataan (P2), (P3) dan (P4) berikut ini:

"hari ini saya tadi udah jalan ke kamar mandi tapi kalau sendiri belum berani kan nggak ada yang pegangin infus, tadi ditemani sama keponakan saya, jadi saya masih ditemani...”.....(P2)

“...kalau ke kamar mandi kalau nggak ditemani saya nggak berani soalnya masih ngerasa pusing jadi takut jatuh...kalau jalan aja masih belum tegak masih agak bungkuk karena kan masih sakit”.......(P3)

"...saya sekarang udah ngerasa enakan aja mba, udah duduk sebenernya dari kemarin juga udah bisa duduk, ya sama aja laha pergerakannnya kaya kemarin, duduk, jalan-jalan, kalau 
sekarang saya ke kamar mandi sendiri aja, saya bolak-balik aja sendiri ke kamar mandi...”....(P4)

\section{Ketakutan dan nyeri akan luka membuat tidak melakukan mobilisasi dini segera}

Beragam alasan disampaikan oleh keempat partisipan. Tiga dari empat partisipan takut untuk melakukan mobilisasi dini dikarenakan takut akan luka jahitan lepas atau robek atau tidak sembuh, sementara satu orang partisipan lainnya menyampaikan bahwa alasan tidak melakukan mobilisasi dini segera karena nyeri. Saat ditanya nyeri terhadap apa, partisipan tersebut menjawabnya dengan nyeri akibat terdapat luka di daerah abdomennya. Hal ini nampak pada pernyataan (P2) dan (P4) berikut ini:

"iya mbak, ada rasa takut waktu saya coba buat gerak-gerak...ya yang saya takutin ya itu takut luka operasinya nggak sembuh, kan baru banget dioperasi jadi takut jahitannya lepas...”. (P2)

"...kalau lagi duduk atau gerakgerakin badan ada terasa nyeri ya saya nggak lanjutin paling saya iduran atau istirahat dulu sampai nyerinya hilang.. "...... (P4)

Berbagai alasan yang disampaikan oleh keempat partisipan juga diperkuat oleh pernyataan partisipan pendukung yang menyatakan bahwa biasanya pasien tidak melakukan mobilisasi dini segera dikarenakan pasien takut, nyeri dan tidak paham akan manfaatnya. Seperti pernyataan berikut ini :

"biasanya pasien tidak melakukan mobilisasi dini itu karena pasien itu takut dan tidak paham, kebanyakan kan pasien dan keluarganya masih awam tentang mobilisasi dini...”......... (Pp)

Instruksi Dokter atau Perawat untuk Melakukan Mobilisasi Dini

Salah satu hal yang menyebabkan keempat partisipan mau melakukan mobilisasi dini atau pergerakan setelah operasi adalah karena adanya orang yang dianggap penting bagi keempat partisipan yang dapat dijadikan acuan untuk melakukan tindakan tersebut. Misalnya seorang dokter atau perawat. Keempat partisipan mengatakan bahwa mereka melakukan mobilisasi dini karena sudah dibolehkan untuk bergerak oleh dokter atau perawat. Seperti yang diungkapkan oleh (P3) berikut ini:

“...perawatnya baru ngasih tahu baru tadi sekitar jam 1/2 10an, terus dokternya juga nyaranin harus gerakgerak kiri kanan, duduk, kalau bisa jalan...tapi saya belum berani, saya baru miring ke kiri aja..."..... (P3)

\section{Dukungan keluarga untuk melakukan mobilisasi dini}

Tiga partisipan mengatakan, jika tidak ada yang menemani atau membantu untuk berajalan ke kamar mandi mereka tidak akan berani untuk melakukan mobilisasi dini sendiri. Ketiga partisipan hanya akan melakukan mobilissai dini di tempat tidur, seperti menggerakkan kaki, miring kanan miring kiri atau hanya tiduran/istirahat saja di tempat tidur bahkan ada yang hanya menggeserkan kepala saja.

Satu orang partisipan aktif dan melakukan mobilisasi dini secara mandiri. Hal tersebut seperti yang disampaikan (P1) dan (P4) berikut ini:

“...kalau nggak ada yang bantuin ya saya tiduran aja paling miring-miring aja di tempat tidur,,,kalau ke kamar mandi nggak berani sendiri soalnya masih ada rasa takut juga..."............... (P1)

"saya sih nggak masalah, orang jalan aja sendiri ke kamar mandi juga nggak apa-apa...”.... (P4)

\section{Harapan setelah melaksanakan mobilisasi dini}

Hasil wawancara menyatakan bahwa keempat partisipan memiliki motivasi yang tinggi untuk sembuh, agar dapat kembali ke aktivitas sebelumnya dan dapat bekerja lagi menyebabkan keempat partisipan melakukan mobilisasi dini setelah operasi. Seperti pernyataan (P2) berikut ini: 
"ya, ikutin anjuran dokter aja untuk gerak, kata dokter kan kalau kitanya rajin buat gerak-gerakin badan katanya badannya enakan, sudah ngerasa pulih jadi biar sembuh dan bisa cepet pulang, terus saya bisa dagang lagi mbak...".......... (P2)

\section{Pembahasan}

\section{Pengetahuan tentang mobilisasi dini}

Mobilisasi dini merupakan intervensi mandiri keperawatan yang dapat dilatih oleh perawat sebelum atau setelah pasien menjalani operasi. Pada penelitian ini, semua partisipan tidak sepenuhnya mengetahui akan pengertian, tujuan, manfaat, tahap-tahap mobilisasi dini. Hal ini dapat dipengaruhi beberapa faktor, seperti pendidikan. Pendidikan akhir keempat partisipan adalah SD dan SMA.

Penelitian Rismalia (2012) yang menyimpulkan bahwa bahwa pengetahuan responden yang kurang menjadi sebab keengganan melakukan mobilisasi dini. Kurangnya pengetahuan responden dikarenakan partisipan belum pernah mendapatkan informasi mengenai mobilisasi dini. Umumnya, perilaku partisipan untuk melakukan mobilisasi dini karena mengikuti anjuran perawat atau dokter, jika dokter atau perawat telah menganjurkan untuk melakukan mobilisasi dini maka partisipan itu mau untuk melakukan mobilisasi dini.

Seperti yang diungkapkan oleh (P3) sebagai berikut: “...perawatnya baru ngasih tahu baru tadi sekitar jam 1/2 10an, terus dokternya juga nyaranin harus gerak-gerak kiri kanan, duduk, kalau bisa jalan...tapi saya belum berani, saya baru miring ke kiri aja...”..... (P3)

Hal ini dapat disimpulkan bahwa sebagian besar partisipan kurang mengetahui tentang mobilisasi dini sehingga mengakibatkan partisipan malas untuk mobilisasi dini.

Pengetahuan juga dipengaruhi oleh beberapa faktor diantaranya adalah terpaparnya seseorang terhadap informasi. Hal ini juga sesuai dengan teori Mubarak (2007) yang menyatakan bahwa kemudahan untuk memperoleh informasi akan membantu mempercepat seseorang untuk memperoleh pengetahuan baru.

Jadi semakin banyak sesorang terpapar dengan informasi kesehatan maka pengetahuannya akan bertambah dan menjadi lebih baik, dibandingkan dengan orang yang jarang dan tidak pernah terpapar dengan informasi kesehatan.

Berdasarkan uraian di atas maka dapat dinyatakan bahwa pendidikan dan paparan informasi merupakan faktor penting dalam membentuk pengetahuan seseorang. Selain itu juga ada keterkaitan antara tingkat pendidikan dengan paparan informasi. Dengan demikian partisipan akan lebih mudah untuk berpikir atau

mendapatkan informasi tentang mobilisasi dini dipengaruhi oleh tingkat pendidikan seorang yang cukup baik pula. Semakin tinggi pendidikan seseorang, maka semakin mudah pula mereka menerima informasi.Selain ditunjang dari tingkat pendidikan formal, pengetahuan juga dapat dipengaruhi dari pendidikan non formal seperti informasi yang didapatkan dari penyuluhan oleh tenaga medis maupun nonmedis serta informasi dari media elektronik.

\section{Perilaku mobilisasi dini pada hari pertama sampai hari ketiga setelah operasi}

Perilaku yang ditunjukkan keempat partisipan terhadap pelaksanaan mobilisasi dini yaitu, semua melakukan mobilisasi dini, namun perlu penguatan dari tenaga kesehatan. Hasil penelitian ini juga sesuai

dengan teori menurut Wawan dan Dewi (2010), yang mengatakan sikap (attitude) merupakan konsep paling penting dalam psikologi sosial yang membahas unsur sikap baik sebagai individu maupun kelompok. Melalui sikap, kita memahami proses kesadaran yang menentukan tindakan nyata dan tindakan yang mungkin dilakukan dalam 
kehidupan sosialnya. Dan sesuai dengan teori Notoadtmodjo (2010) yang mengatakan bahwa sikap merupakan pendapat atau penilaian orang atau responden terhadap hal yang terkait dengan faktor resiko kesehatan.

Sikap terdiri dari berbagai tingkatan seperti menerima, merespon, menghargai, dan bertanggung jawab. Mengacu pada tingkatan sikap yang disebutkan di atas, dapat dijelaskan bahwa tingkatan sikap partisipan mengenai mobilisasi dini persentase terbesar dalam kategor baik dapat dikelompokkan pada tingkatan mampu menerima dan mampu merespon, menghargai dan bertanggung jawab dalam latihan mobilisasi dini.

Hal ini ditunjukkan oleh pernyataan (P4) sebagai berikut: “...saya sekarang udah ngerasa enakan aja mba, udah duduk sebenernya dari kemarin juga udah bisa duduk, ya sama aja laha pergerakannnya kaya kemarin, duduk, jalan-jalan, kalau sekarang saya ke kamar mandi sendiri aja, saya bolakbalik aja sendiri ke kamar mandi...”.

Upaya peningkatan sikap seseorang dapat dilakukan dengan dasar belajar yang diperoleh dari pengalaman seseorang hasil mengamati, mendengar dan membaca. Peningkatan sikap responden dapat dilakukan dengan memberi informasi kesehatan melalui penyuluhan, dengan melakukan model, pengalaman dan diskusi kelompok serta bermain peran.

Beberarapa teori yang telah dicoba untuk mengungkapkan determinan perilaku dari analisis faktor-faktor yang mempengaruhi perilaku yang berhubungan dengan kesehatan, salah satunya adalah dari teori Lawrence Green. Menurut Lawrence Green (1965) dalam Notoatmodjo (2012) mengatakan bahwa perilaku itu ditentukan dan terbentuk dari 3 faktor, yaitu faktor predisposisi berupa dalam pengetahuan, sikap, kepercayaan, keyakinan, dan nilainilai. Yang kedua yaitu faktor pendukung beerupa lingkungan fisik, tersedia atau tidak tersedianya fasilitas-fasilitas atau saranasarana kesehatan, misalnya puskesmas, dan obat-obatan. Serta ketiga adalah faktor pendorong berupa sikap dan perilaku petugas kesehatan, atau petugas yang lain, yang merupakan kelompok referensi dari perilaku masyarakat.

Notoatmodjo (2012) mengatakan bahwa, tindakan adalah realisasi dari pengtahuan dan sikap menjadi suatu perbuatan nyata. Tindakan juga merupakan respon seseorang terhadap stimulus dalam bentuk nyata atau terbuka.

Respon terhadap stimulus tersebut sudah jelas dalam bentuk tindakan atau praktek, yang dengan mudah dapat diamati atau dilihat oleh orang lain. Suatu sikap belum tentu terwujud dalam tindakan, untuk terwujudnya suatu tindakan (perbuatan yang nyata) dibutuhkan suatu pendukung atau suatu kondisi yang memungkinkan, antara lain adalah fasilitas dan dukungan dari berbagai pihak. Adanya hubungan erat antara sikap dan tindakandidukung oleh pengertian sikap yang menyatakan bahwa sikap merupakan kecendrungan untuk bertindak.

\section{Ketakutan dan nyeri akan luka membuat tidak melakukan mobilisasi dini segera}

Ungkapan dan ekspresi keempat partisipan saat ditanya apa yang menjadi alasan partisipan untuk melakukan mobilisasi dini segera, keempatnya memiliki jawaban yang berbeda-beda namun memiliki tema yang sama yaitu, ketakutan nyeri akan luka operasi yang menghambat mereka melakukan mobilisasi dini. Seperti yang disampaikan oleh (P2) dan (P4).

Menurut Anggraini Mega (2013) mobilisasi adalah kemampuan seseorang untuk bergerak secara bebas, mudah dan teratur yang bertujuan untuk memenuhi kebutuhan hidup sehat. Setiap orang pasti membutuhkan untuk bergerak. Seseorang yang kehilangan kemampuan untuk bergerak akan menyebabkan 
ketergantungan pada orang lain sehingga dibutuhkan tindakan keperawatan.

Mobilisasi dini dibutuhkan untuk meningkatkan kemandirian diri, meningkatkan kesehatan, memperlambat proses penyakit degenerative dan untuk aktualisasi diri. Mobilisasi sangat penting untuk percepatan hari rawat dan mengurangi resiko-resiko akibat tirah baring lama seperti terjadinya dekubitus, kekakuan/penegangan otot-otot- seluruh tubuh dan sirkulasi daran dan pernapasan terganggu, juga adanya gangguan peristaltik maupun berkemih. Sering kali dengan keluhan nyeri di daerah operasi klien tidak mau melakukan mobilisasi ataupun dengan alasan takut jahitan luka operasi lepas sehingga klien tidak berani merubah posisi.

Hal ini sesuai dengan teori yang telah disampaikan oleh Notoatmodjo (2012) diatas bahwa tindakan menjadi relisasi dari pengetahuan dan sikap seseorang untuk melakukan tindakan. Menurut peneliti tidak baiknya tindakan seseorang dapat disebabkan karena pengetahuan dan sikap responden yang kurang baik, sehingga sangat diperlukan sekali penyuluhan/pendidikan kesehatan mengenai mobilisasi dini.

Perilaku merupakan respon suatu reaksi seorang terhadap stimulus (rangsangan dari luar). Oleh karena perilaku ini terjadi melalui proses adanya stimulus terhadap individu dan kemudian individutersebut merespon (Notoatmodjo, 2012).

\section{Kesimpulan}

Penelitian ini memberikan gambaran perubahan pengetahuan, sikap dan perilaku akan pentingnya mobilisasi dini. Upaya untuk meningkatkan partisipasi pasien post operasi laparotomi secara mandiri dalam mobilisasi dini dimulai dengan meningkatkan pengetahuan dan sikap pasien tersebut terhadap mobilisasi dini.

Pemberian edukasi dan informasi yang benar tentang mobilisasi dini pada pasien post operasi laparotomi dan keluarganya menjadi hal paling penting untuk dilakukan. Peningkatan kualitas edukasi dam dukungan (support system) dari petugas kesehatan dan operasi laparotomi diharapkan meningkatkan patisipasi mandiri pasien dalam melakukan mobilisasi dini paska operasi. Diharapkan hasil penelitian ini dapat menjadi tema penelitian lanjutan

\section{Ucapan Terima Kasih}

Akademi Keperawatan Fatmawati yang telah membantu pembiayaan dan pendanaan penelitian. Pihak RSUP Fatmawati tempat penelitian dilaksanakan yang telah memberikan banyak bantuan terlibat penelitian dan seluruh perawat yang bersedia ikut berpartisipasi sehingga penelitian ini dapat selesai, serta keluarga yang senantiasa memberikan dukungan secara materil dan non materi.

\section{Daftar Pustaka}

Anggraini, Mega. (2013). Pengaruh mobilisasi dini terhadap keberhasilan penyembuhan luka pada pasien pasca operasi di RS. Muhammadiyah

Yogyakarta. Diunduh dari http://opac.unisayogya.ac.id/385/1/ NASKAH\%20PUBLIKASI\%20ME GA.pdf.

Epiana, R. (2014). Hubungan motivasi dengan latihan mobilisasi pada pasien post operasi appendicitis di RSUD DR. Moewardi. Skripsi (tidak diterbitkan). Surakarta: STIKES PKU Muhammadiyah Surakarta.

Gusti, \& R.P. (2011). Pengaruh mobilisasi dini pasien pasca operasi abdomen. Ners Jurnal Keperawatan, 106-113.

Haryanti, L., Pudjiadi A.H., Ifran, E.K.B., Thayeb, A., Amir, I., Hegar, B. (2013). Prevalens dan Faktor Risiko Infeksi Luka Operasi Pasca-bedah. Sari Pediatri. 15 (4). 
Hasbullah.(2012). Dasar - dasar ilmu pendidikan. Jakarta: Rajawali Pers

Hurlock, E.B. (2008). Psikologi perkembangan. Jakarta : Erlangga

Kiik, S.M. (2013). Early mobilization influence to peristaltic's recovery time intestine on pasca's patient hads out abdomen at icu bprsud labuang baji makassar. Health Journal, 1 (1),

Marlitasari, H., Ummah B., \& Iswati N. (2010). Gambaran penatalaksanaan mobilisasi dini oleh perawat pada pasien post appendiktomy di RS PKU Muhammadiyah Gombong. Jurnal Ilmiah Kesehatan Keperawatan, 2 (6), 48-54.

Mubarak, W. I., Chayatin, N., Rozikin, K. \& Supradi. (2007). Promosi kesehatan: sebuah pengantar proses belajar mengajar dalam pendidikan. Yogyakarta: Graha Ilmu.

Nainggolan, E. \& Simanjuntak, L. (2013). Hubungan mobilisasi dini dengan lamanya penyembuhan luka pasca operasi appendiktomi di Zaal C Rumah Sakit HKBP Balige Tahun 2013. Jurnal Keperawatan
HKBP Balige, 1(2), (Online). Di akses dari http://www.akperhkbp.ac.id/wpcontent/uploads/2014/03/

Notoatmodjo, S. (2010). Promosi dan perilaku kesehatan. Jakarta: Rineka Cipta.

Notoatmodjo, S. (2012). Promosi kesehatan dan perilaku kesehatan. Jakarta: Rineka Cipta.

Potter, P.A., \& Perry, A.G. (2010). Fundamental of nursing. Jakarta: Salemba Medika.

Rismalia, R. (2012). Gambaran pengetahuan dan perilaku pasien pasca operasi appendectiomy tentang mobilisasi dini di RSUP Fatmawati. Jakarta: Fakultas Kedokteran dan Ilmu Kesehatan UIN.

Sartika, D.H.B., \& Suarnianti, I.H. (2013). Pengaruh komunikasi terapeutik terhadap tingkat kecemasan pada pasien pre operasi di Ruang perawatan Bedah RSUD Kota Makassar Tahun 2013, 3. (3), ISSN : $2302-1721$. 